\title{
76654
}

\section{Competition and Scope of Activities in Financial Services}

Stijn Claessens • Daniela Klingebiel

This article analyzes the costs and benefits of different degrees of competition and different configurations of permissible activities in the financial sector and discusses the related implications for regulation and supervision. Theory and experience demonstrate the importance of competition for efficiency and confirm that a competitive environment requires a contestable system - meaning one that is open to competition — but not necessarily a large number of institutions. A competitive banking system can improve the distribution of consumer credit, enhance the corporate sector's access to financing, and mitigate the risks of financial crises. In an open market, in which services and products are provided in response to market signals, financial institutions respond by offering a wider scope of financial services. The optimal institutional design for supervisory functions is less obvious.

In examining the framework for a country's financial system, it is useful to start with the laws that govern its financial institutions, such as central and commercial bank regulations, deposit insurance (if such a scheme exists), securities market requirements, and relevant international agreements. These laws and regulations define the roles and activities of commercial banks relative to those of nonbank financial institutions, influence the degree of competition in the financial system, define the degrees and modes of permissible entry, and specify the responsibilities of supervisory agencies. This framework and how it is enforced determine the structure, stability, and efficiency of a country's financial system.

This article reviews alternative frameworks for financial services markets from an economic perspective using experiences in several countries as a guide. We then analyze the effects of different degrees of competition in the financial sector, examine the costs and benefits of different configurations of permissible activities for financial institutions, and discuss the implications for regulatory and supervisory structures. We focus first on the role of competition in the financial sector and the tradeoffs between competition on the one hand and stability and innovation on the other. We next examine alternative structures of financial services dictated in many countries 
by government policies rather than by the market. After discussing the advantages and disadvantages of integrated banking and other financial system configurations, we review the empirical evidence on this issue and analyze the pros and cons of different supervisory structures.

\section{Competition and Contestability}

It is important to encourage low costs and product innovations in financial intermediation. Generally, competition leads to these benefits. But unlike other sectors, in which unfettered competition is often preferable from the perspectives of efficiency, stability, and growth, competition in financial markets cannot be considered in isolation. In establishing a competitive environment, the following issues arise: franchise value, static and dynamic efficiency, the ability to supervise financial institutions and activities, and rent seeking. Financial sector rules generally aim to balance these objectives and concerns.

\section{Competition and Consolidation}

Competition in the financial sector plays an important role in ensuring the benefits of static and dynamic efficiency. Empirical evidence indicates that many financial institutions are so inefficient that this concern actually dominates such issues as whether financial institutions are too large or too small to benefit from economies of scale. (For studies on industrial countries, see Berger, Hunter, and Timme [1993]; for developing countries, see Barajas, Steiner, and Salazar [1999], Bhattacharya, Lovell, and Sahay [1997] and Hao, Hunter, and Yang [1999]; for five East Asian countries, see Laeven [1999]; and for a cross-country study, see Demirgüç-Kunt and Huizinga [1999].) The findings are generally similar: Many banks operate below their technical possibilities, and measures that would induce financial institutions to act efficiently from the standpoint of costs are essential. The most important of these measures is competition, which has been found to affect performance measures in a wide variety of countries.

In determining the level of competition in a banking system, entry policies-not actual entry-are important (Vives 2000). A competitive financial system does not necessarily require a large number of financial institutions; a concentrated system can be competitive if it is contestable (that is, if competition is open). Financial systems in many European countries are considered to be quite competitive even though they have a limited number of banks; often, in fact, the combined market share of the top three banks in a country exceeds 30 percent. In reporting on Canada, for example, Shaffer (1993) finds no evidence of monopolistic behavior even though the 
five largest banks in the country account for more than 80 percent of all banking assets.

Banking systems are also highly concentrated in developing countries, but many of these systems are not considered competitive. One difference is that competition from other financial institutions and other forms of financial intermediation is stronger in more developed capital markets. Moreover, financial institutions in such markets face a credible threat from new entrants that are permitted to offer rival services in the market and are encouraged to do so by a transparent licensing process. This threat of competition is not always present in developing countries, where regulatory barriers often limit entry, especially by foreign financial institutions. Allowing entry does not mean that any number of banks can enter the market; all countries maintain some limits for prudential reasons. When moving from a closed to a more open system, a transition period is necessary to allow domestic financial institutions to adjust and maintain profitability. One option is to set a firm timetable for opening the market - a timetable that is made binding through domestic laws and regulations and possibly backed up through international agreements. This credible threat of entry precludes political wrangling by existing banks.

Just as contestability and concentration are not necessarily inconsistent, increased competition and greater consolidation of banking institutions need not be inconsistent. The European Union's Single Market Program involved both considerable consolidation within countries as well as increased competition (Gardener and others 2000; Vives 2000). The new program enhanced domestic financial reform efforts, including the competitive framework, in many member countries of the European Union. Barajas, Steiner, and Salazar (1999), Clarke and others (2000), and Denizer (1997) observed the same improvement in developing countries. The current trend toward global consolidation appears to be driven by economies of scale and scope rather than by a desire to carve up certain markets (Berger, Demsetz, and Strahan 1999).

\section{Tradeoff between Competition and Stability}

Experience and theory show a tradeoff between competition and a stable and sound financial system. Financial institutions can be adversely affected by intense competition that encourages unrealistic rates on deposits and loans and undermines profitability, thereby weakening the incentive for financial institutions to act prudently. Gruben and McComb (1999) find, for example, that as a result of Mexico's large-scale privatization in 1991-92, marginal costs exceeded marginal revenues, imposing losses and increasing the incentive for financing risky projects. This excessive competition contributed to the financial instability that culminated in the 1994-95 crisis. The fact that the benefits of liberalization and increased competition under the European Union's Single Market Program have been realized without significant 
banking crises can be attributed in part to associated re-regulation efforts, including tighter capital adequacy and other prudential requirements, and an increased emphasis on supervision.

Entry policies can help achieve the balance between profitability and competition. Entry barriers alone, however, contribute to rent seeking, discourage efficiency improvements, and result in limited incentives for innovation. Moreover, entry has to be considered in relation to exit. Policymakers need to make clear to the financial institution's owners, managers, and investors that inefficient and imprudent behavior will result in the institution's failure or closure. In many developing countries, exit processes for financial institutions have been very weak, leaving the financial sector with many undercapitalized institutions and unfair competition from weak banks that have been allowed to continue operating.

Entry and exit policies alone may not ensure a stable financial system. Additional instruments may be necessary to balance competition and profitably, especially in developing countries. Honohan and Stiglitz (1999) identify four additional instruments that are necessary to strike a balance between competition and profitability: minimum absolute capital requirements, capital adequacy requirements as a fraction of risk-weighted assets, ceilings on deposit rates, and limits on portfolio composition or lending activities. Each instrument has negative side effects, including rent seeking, disintermediation, and monitoring costs (table 1). Most countries have used a combination of these tools at different times in the development of their financial sectors. All countries today, for example, have some form of capital adequacy requirement. Simple tools, such as limits on risk exposures or on the total growth of assets, may be useful if the quality of financial information is weak, the capacity of the supervisory authority is stretched, and the risk-management capacity of the banking sector is limited. Many countries have liquidity requirements, for example, that restrict banks' portfolios. Identifying the proper mix of regulatory instruments requires a dynamic analysis of the potential profitability of financial institutions under different regulatory paths and states of the economy (Stiglitz 1999).

\section{Benefits and Costs of Foreign Entry}

Openness to foreign entry can be an important element in determining the degree of contestability (Claessens and Glaessner 1999; Levine 1996). Although foreign entry (as any other entry) can lower profitability, it can also have separate, offsetting benefits. In an 80-country study of 2,000 banks ( 500 of which were foreign), Claessens, Demirgüç-Kunt, and Huizinga (2001) found that in countries with more extensive foreign ownership, the domestically owned banks were less profitable and recorded lower overall expenses. This suggests that competition from foreign banks puts pressure on domestic banks to improve productivity and services and that access to foreign expertise helps domestic banks become more efficient. Research in Argentina 


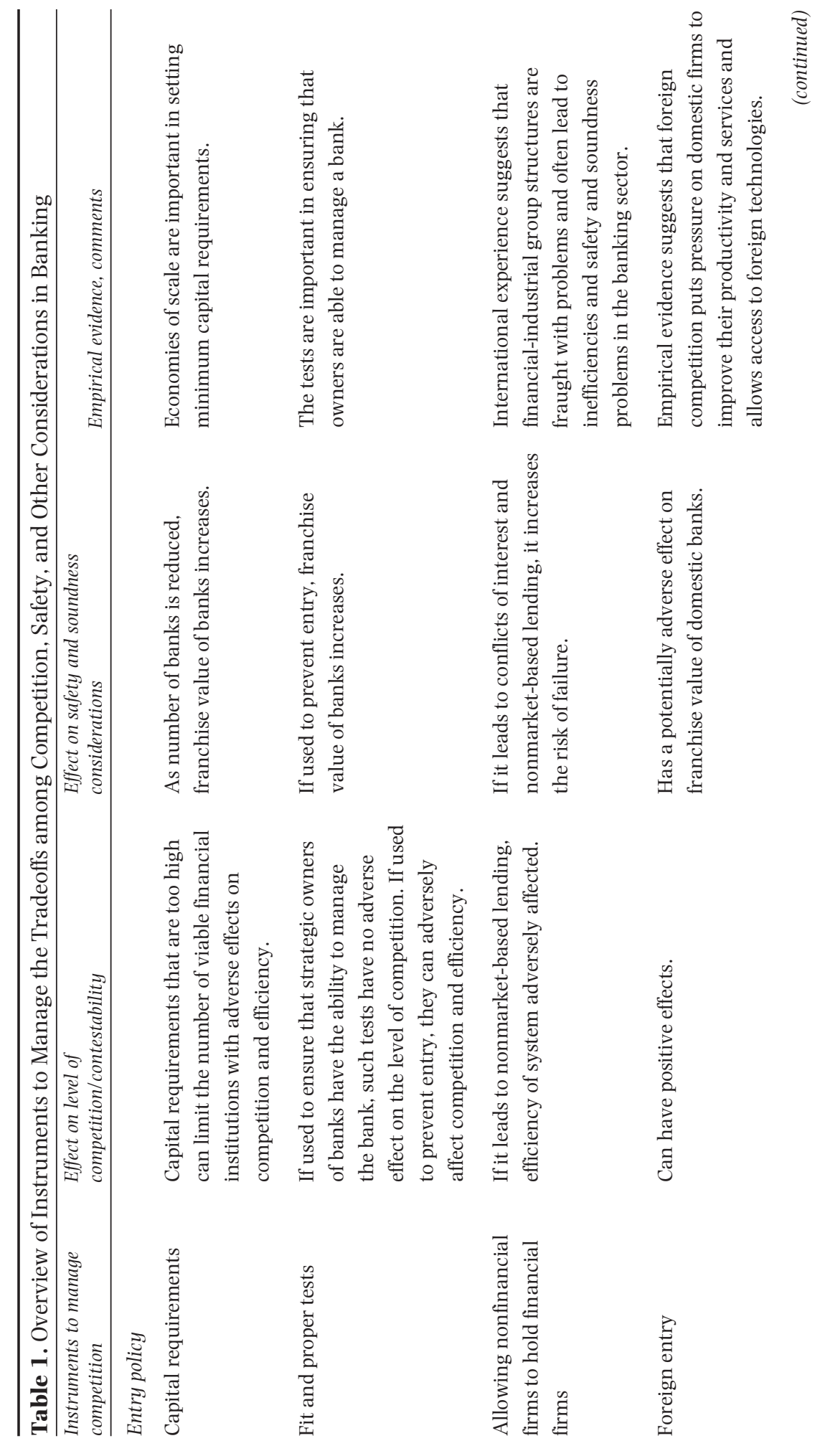




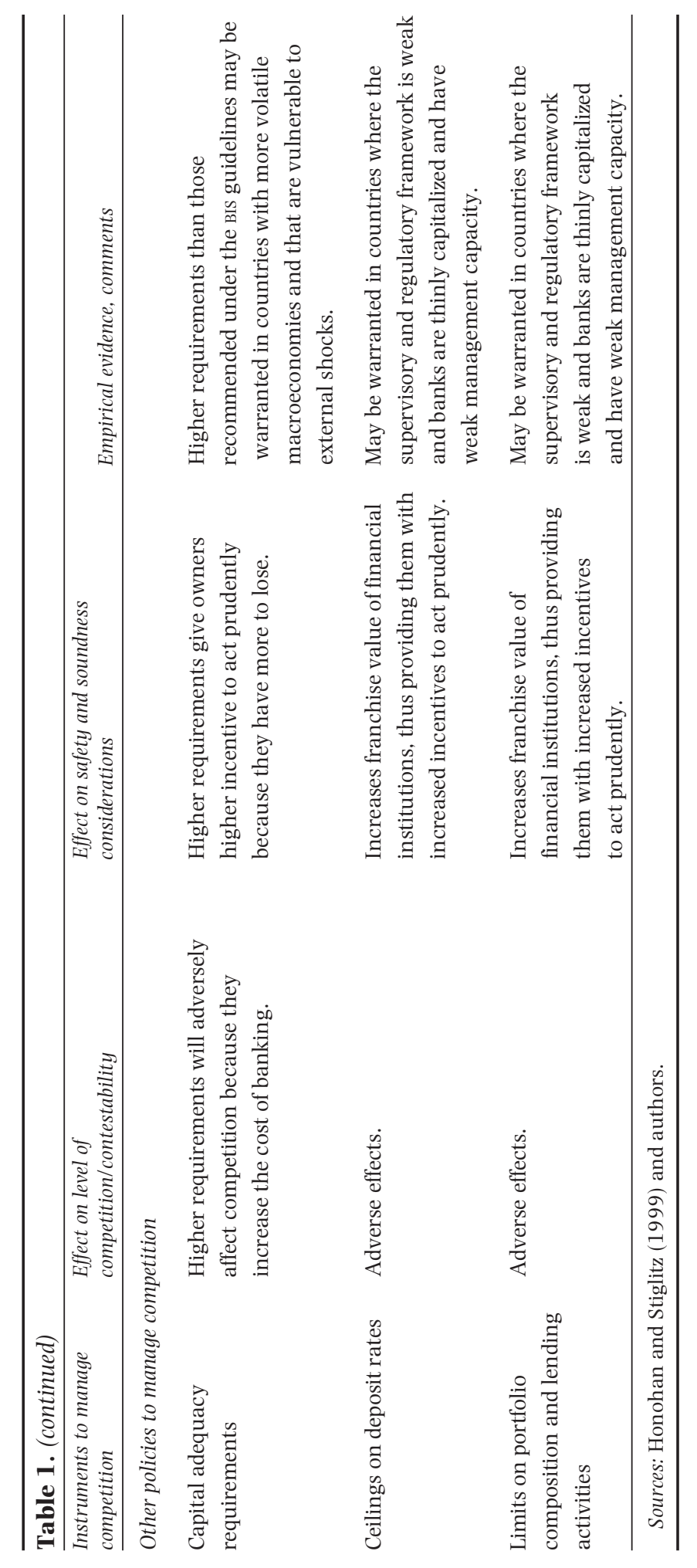


(Clarke and others 2000), Colombia (Barajas, Steiner, and Salazar 2000), Hungary (Kiraly and others 2000), Ireland and Portugal (Honohan 2000), Spain (Pastor, Perez, and Quesada forthcoming), Turkey (Denizer 2000), and other countries that opened up internationally and deregulated domestically shows that the liberalization led to substantial gains.

Increased foreign entry also improves the framework for financial services by creating a constituency for better regulation and supervision, greater disclosure, and other improvements. Openness can also add to the credibility of rules. Countries that joined the European Union, for example, consolidated reform efforts and aligned regulatory regimes while also opening their markets to foreign financial intermediaries (see, for example, Pastor, Perez, and Quesada [2000] for the case of Spain and Honohan [2000] for Portugal).

Foreign banks active in emerging market economies typically tend to focus their activities on large corporations. Therefore, reduced access to services as a result of foreign competition has been a concern. Clarke and others (2000) find that foreign banks entering Argentina in the mid-1990s did not merely follow their clients abroad. They also exerted competitive pressure on domestic banks, especially those focused on mortgage lending or manufacturing, suggesting that foreign banks expanded especially in these sectors. Overhead, profitability, and interest margins were affected least in the domestic banks that focused on consumer lending, an area in which foreign investors showed little interest.

Demirgüç-Kunt, Levine, and Min (1998) find that a foreign presence had a positive effect on the stability of the financial sector. It is important, however, to ensure sufficient diversity in terms of the participants' country of origin to avoid the risks that a shock in a single home country would affect its bank branches abroad. Not all foreign banks are equally good; it is essential that the licensing process be transparent and include detailed information about owners, managers, and qualifying criteria.

\section{The Scope of Permissible Activities}

In most countries, regulation (rather than competition) determines the range of products and services a bank can offer, the types of assets and liabilities it can hold and issue, and the legal structure of its organization. Differences in corporate structures, however, have distinct advantages and disadvantages. Of growing importance is the global trend toward increased substitutability between various types of financial instruments. In many countries, bank deposits compete with other liabilities of financial intermediaries, such as money market funds, in the provision of liquidity and payment services. On the one hand, this competition implies that the demarcation lines between different types of financial intermediaries have become increasingly blurred from both the consumers' and the producers' points of view. On the other 
hand, even as these regulatory barriers have become less effective, the economic costs of maintaining them have risen.

\section{The Structure of the Financial System}

It is useful to distinguish between two models of financial services: The first prohibits banks from engaging in any type of securities transactions or other noncredit financial service activity; the second permits banks to provide a variety of financial services, either directly or indirectly through subsidiaries. The latter is often called "universal banking." Because other aspects—-such as the ownership of nonfinancial institutions - are often associated with universal banking, we use the term "integrated banking" to refer to a banking structure that permits a single institution to offer a scope of financial services.

Integrated banking is the norm around the world. Of 51 industrial and emerging countries surveyed by the Institute of International Bankers in 1998, only China has a completely "pure" separate banking system-in the sense that banks are not allowed to engage in any type of securities activities. Thirty-six of the countries surveyed, including all the eu countries, allow the same banking organization to handle banking, securities trading, and underwriting. In 15 countries financial institutions are allowed to engage - to varying degrees - in securities activities, either through a bank parent (12) or a bank holding company structure (3). The United States is the most prominent country with a bank holding company structure that also restricts the type of securities businesses that commercial banks can undertake (see Claessens and Klingebiel 1999). ${ }^{1}$

Three benefits have been identified with fully integrated banking: First, it allows for the use of informational advantages; second, it increases profits through economies of scale and scope; and, finally, it reduces the variability of profits (table 2).

Informational advantages. In establishing a relationship with a company, a bank incurs costs gathering information about the firm's financial condition and its investment decisions. The longer the expected duration of the relationship, the more likely the bank will invest in gathering firm-specific information-information that may lead to an increase in the financing available. Integrated banks have lower overall information and monitoring costs because they can offer a broader set of financial products than can specialized banks. For example, an integrated bank can use information derived from managing a basic bank account to provide other financial services. If the bank holds ownership in a corporation, it may have representation on the board of directors, which can be useful in acquiring information for its lending activities. An integrated bank can also design financing contracts better suited to the borrower's activities. Finally, as a firm switches from bank financing to raising money 
Table 2. Overview of Benefits and Costs of Integrated Banking

\section{Potential benefits}

Informational advantages

- Banks can obtain more information about firms through the various products the banks offer.

- Banks and firms have potential to develop a longer-term relationship that may improve access to bank financing and better financing conditions for the borrower.

Economies of scope

- Cost economies can derive from access to information, management of the client relationship, distribution and marketing economies, reputational and pecuniary capital economies, and risk management.

- Economies on the consumer side include the potential for lower search, information, monitoring, and transaction costs; the potential to negotiate better deals; and the potential for lower product prices in a competitive market.

Economies of scale

- Exploitation of scale economies can save costs in overhead, back office operations, information technology, and investment banking-type operations.

- Size may also help in exploiting economies of scope.

Risk diversification

- Integration can provide banks with higher profits in periods of disintermediation.

- Integration can produce more stable income streams.

Increase in revenue generation

- Cross-selling of different services and products should allow banks to increase revenues.

\section{Potential costs}

Conflicts of interest

- Banks might abuse the trust of their customers by selling low-quality securities without revealing the risks.

Reduction in competition

- Integrated banking may reduce the scope for competition. There may be a tradeoff between safety and soundness considerations (higher franchise value of integrated banks) and a reduction in competition. A liberal entry policy may counterbalance this disadvantage to a certain degree. Yet from a political economy standpoint, a liberal entry policy may be difficult to sustain if economic power (that is, the banking system) is concentrated.

Concentration of economic and political power

- Integrated banking may lead to a concentration of economic and hence political power. No specific evidence confirms or refutes this concern.

Monitoring

- Integrated banks are more difficult to supervise and more difficult for the market to monitor.

Expansion of safety net

- The safety net of depository institutions may be extended to investment activities of integrated banks. Exposure can be limited with policy measures, such as market value accounting, risk-sensitive insurance premiums, and capital requirements, and by adopting procedures for taking prompt corrective action.

Source: Authors. 
on the capital markets, it can remain a customer if the bank provides both lending and securities underwriting services.

Empirical research confirms that the close bank-firm relationship associated with integrated banking can be a source of important benefits to firms in terms of cost and availability of funding (Berger and Udell 1995; Petersen and Rajan 1994). Essentially, informational advantages associated with integrated banking can turn advantages for banks into advantages for customers, who get better and cheaper services. The degree to which these informational advantages can be realized and passed on to the customer depends, of course, on the degree of informational asymmetries: In economies where information is generally poor, close bank-firm relationships could in principle be very useful. ${ }^{2}$ Under such circumstances, however, banks are likely to be weakly monitored themselves, a situation that risks poor resource allocation.

Economies of scope and scale. Economies of scope may arise from both the production and the consumption of financial services (Saunders and Walter 1994). Integrated banks have several specific cost advantages, such as better access to and dissemination of information across different product groups, greater distribution and marketing economies in the delivery of services, shared reputational and pecuniary capital across different products and services, and enhanced potential for risk management because of the gains of diversification. On the consumption side, economies of scope may derive from lower costs, including the potential to reduce search, information, monitoring, and transaction costs; consumers may also be able to negotiate better deals because of increased leverage. In a competitive environment these lower costs will translate into lower product prices.

In terms of economies of scale, most empirical studies have found that the bulk of scale economies are captured, but not fully exhausted, by the time a bank has $\$ 2$ billion to $\$ 10$ billion in assets. ${ }^{3}$ Early studies for U.S. banks found that economies of scale were exhausted at much lower levels (Clark 1988). Later studies found evidence of scale economies up to the level of \$2-10 billion in assets (Hunter, Timme, and Yang 1990; Noulas, Ray, and Miller 1990). Other empirical evidence for U.S. banks suggests that economies of scale actually may start to decline for asset sizes between $\$ 10$ billion and \$25 billion (Berger, Hunter, and Timme 1993). The few tests that have been conducted for other countries largely confirm these results. In studies based on non-U.S. data, Saunders and Walter (1994) and Vander Vennet (1994) found economies of scale in individual loans of up to $\$ 25$ million. Lang and Welzel (1995) found scale economies among German universal banks up to a size of $\$ 5$ billion. Evidence for emerging countries is very limited (Laeven 1999).

There is much less empirical evidence of scope economies, possibly because financial institutions cannot or do not choose their optimal institutional structure. 
The bulk of studies for U.S. banks concludes that economies of scope in banking, if present at all, are exhausted at very low levels of output (Berger, Hanweck, and Humphrey 1987; Berger, Hunter, and Timme 1993). Empirical studies on European banks have been inconclusive. Lang and Welzel (1995) reported the absence of scope economies in German universal banks but found such economies in small cooperative banks. Vander Vennet (1999) found that universal banks are characterized by significantly higher levels of operational efficiency relative to specialized banks.

Barth, Caprio, and Levine (1999) analyzed empirically the costs and benefits of different allowable activities in 60 countries. They found no reliable statistical relationship between regulatory restrictions on commercial bank activities and the level of development in the banking sector, securities markets, and nonbank financial intermediaries or between regulatory restrictions and the degree of industrial competition. Indeed, based on the cross-country evidence, they state that "it would be quite difficult for someone to argue confidently that restricting commercial banking activities benefits or harms financial development, securities market development, or industrial competition" (Barth, Caprio, and Levine 1999:2). They do, however, find that regulatory restrictions on the ability of banks to engage in securities activities tend to be associated with higher interest rate margins for banks. Because there is little relationship between regulatory restrictions on banking powers and overall financial development and industrial competition, the preferred option may be no restrictions.

Increased diversification and lower risk. An integrated bank may be more stable than a specialized bank because of the benefits of diversification. These benefits can arise from two sources. First, disintermediation-where firms bypass banks and raise money directly from public markets-affects integrated banks less than specialized banks because an increase in the integrated banks' underwriting business can offset the decline in their lending business. This in turn may reduce integrated banks' incentives to engage in riskier lending to maintain profits. Second, as a result of diversification, the total profits of an integrated bank are more stable than those of banks specialized in a single product. Although securities subsidiaries of U.S. banks tend to be riskier (profits are more volatile) than banking affiliates, for example, the subsidiaries provide the benefits of diversification (Klein and Saidenber 1998; Kwan 1997).

\section{Potential Risks of Integrated Banking}

Integrated banking can incur costs (John, John, and Saunders 1994), including conflicts of interest, increased financial risks, and monitoring issues. ${ }^{4}$ 
Conflicts of interest. When financial institutions offer a wide array of products and have a broad set of customers, conflicts of interest can emerge. ${ }^{5}$ Such concerns are more important where the bank acts as a broker; they are of less importance where the bank acts on its own account because the bank itself remains exposed. Conflicts have been identified as one of the major potential costs of permitting commercial banks to conduct securities business (Benston 1990; Kelly 1985; Saunders 1985). Typically, a bank is better informed than the public investors about a firm's soundness and prospects. This informational advantage may, however, be a double-edged sword. On the positive side, an integrated bank might be better positioned than a specialized investment bank to certify credibly the value of a security offered by the firm. On the negative side, an integrated bank might have the incentive and the ability to take advantage of investors by selling low-quality securities without revealing risks or by raising lending rates to the same borrower.

The critical issue here is not whether any potential conflicts exist but, rather, whether the incentives to exploit them do. Market forces in general, such as competition from other financial institutions, reduce incentives to exploit conflicts, as do potential damage to reputation and the monitoring by creditors and nonmarket monitors, such as credit-rating agencies. Conflicts therefore tend to be more important in countries where disclosure rules are weak, information on bank activities is hard to find, competition is limited, and supervision is weak. The ability to exploit conflicts can be further restricted by legal constraints (such as disclosure requirements to be met in the issuance and distribution of securities) and private self-regulatory standards (such as information-sharing rules between departments of a bank).

Empirical studies of Germany's universal banking system and of the U.S. financial system before passage of the Glass-Steagall Act in 1933 (a system that in some ways resembles the current situation in many countries) have not found evidence of systematic conflicts of interest (Ang and Richardson 1994; Kroszner and Rajan 1994; Puri 1994, 1996; Ramirez 1995).

Safety, soundness, and the safety net. A combination of securities and commercial banking activities can increase the risk of bank failure (Boyd, Chang, and Smith 1998; Saunders 1994). Although such failures have happened-in emerging as well as in industrialized markets (for example, the United Kingdom's Barings bankruptcy) empirical evidence does not confirm this possibility as a general proposition (White 1986). On the contrary, evidence shows that the combination might well reduce risks. Eisenbeis and Wall (1984) find a negative correlation between U.S. bank earnings and securities broker-dealer earnings in the 1970s and 1980s (see also Benston 1990; and Brewer, Fortier, and Pavel 1989). Barth, Caprio, and Levine (1999) study a large set of countries and find those that impose strict regulatory restrictions on the securities activities of commercial banks have a substantially higher probability of suffering a major banking crisis. More specifically, countries with a regulatory environ- 
ment that inhibits the ability of banks to engage in securities underwriting, brokering, dealing and all aspects of the mutual fund business tend to have more fragile financial systems.

Nevertheless, safeguards can be necessary to avoid the transfer of explicit and implicit deposit insurance subsidies from the banking arm of the institution to the securities arm (Kane 1996; Schwartz 1992). These safeguards can take the form of market-value accounting, timely monitoring and disclosure, more risk-sensitive capital requirements, firewalls between different types of operations, risk-based pricing of deposit insurance, and prompt corrective actions, including the closure of insolvent banks.

Monitoring and supervision. The supervisory functions for commercial banks and securities entities have different objectives. Supervision of commercial banks aims to protect the net worth of the entity and thus the rights of creditors, particularly depositors, as the bank is intermediating third-party money. For securities firms the regulators' objective is to protect the consumer by avoiding abuses arising from the agent-type relationships typical in securities markets. Combining securities and commercial banking activities under one umbrella can make supervision by regulators and monitoring by the market more difficult because the securities business might have an impact on the banking business, but the two activities cannot easily be monitored separately. In this respect, integrated banking can carry more risk.

Corporate structure of banking organizations. The extent to which the potential benefits of integrated banking can be realized depends largely on which of three organizational models is used (table 3): the fully integrated banking model, the bankparent model, or the holding company model. A fourth model, discussed earlier, imposes a complete institutional separation between commercial and investment banking.

- Integrated banking. In countries where banks have latitude to choose their own corporate structure, most adopt the integrated bank model. This way resources can be shared among the organization's various departments with maximum flexibility, allowing the bank to take full advantage of information and economies of scope and scale. Moreover, integration increases a bank's ability to diversify sources of revenue. At the same time, safeguards for heading off conflicts of interest and extending the safety net are limited (Santos 1997a, 1998; Saunders 1994).

- The bank-parent company. In this model, securities transactions are handled by a subsidiary of the bank. Because there is a legal separation, integration of the bank and securities activities is compromised, thus reducing the potential for economies of scope. This model still allows for risk diversification, however, and 


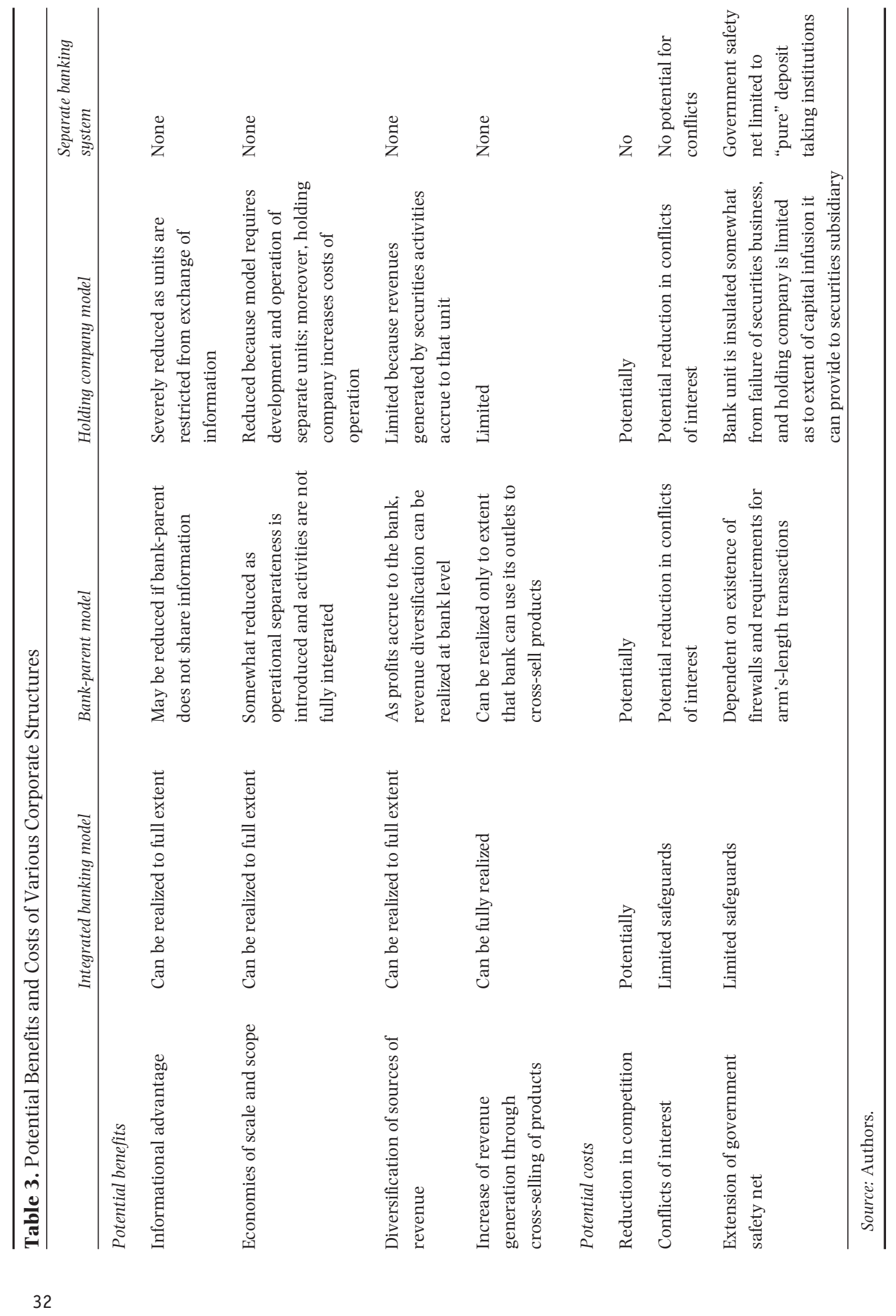


offers the potential for higher revenues through cross-selling of financial services. The bank-parent model can reduce the potential for conflicts of interest and the related extension of the safety net—as long as regulations requiring firewalls between bank and its subsidiaries and prescribing arm's-length transactions are in place.

- The holding company. In this model, a holding company owns both the bank and the securities subsidiary, with a legal separation between the two. Different products are offered by separately capitalized and incorporated units. Each unit has its own management team, accounting records, and capital. This generally limits the exchange of information, personnel, or other inputs, thus reducing economies of scale and scope and constricting the bank's ability to exploit informational advantages. The holding company structure can limit risk diversification potential because revenues generated by securities activities accrue to that unit and then to the holding company. At the same time, the holding company can act as a source of financial strength to the bank subsidiary. The advantages of the holding company model include a reduction in the potential for conflicts of interest and a limit on the extension of the safety net (see Santos 1997b).

\section{The Organization of Supervisory Authority}

All governments, even the most market-oriented ones, regulate the financial sector to protect the public, to guarantee bank safety and soundness, and to monitor the desired degree of competitiveness. The organization of the supervisory structure depends on the policy of the regulatory regime, particularly the allowable scope of financial services. Three issues arise in this connection. Should countries that permit integrated banking locate all prudential and other supervision in one place, or separate it into multiple supervisors? If there are multiple supervisors, should they be arranged by type of institution or by function? Finally, should consumer protection and antimonopoly safeguards be the responsibility of the prudential regulator or of a separate regulator? Some guidance is available from recent analytical work-and from international experience — on the tradeoffs between these alternatives, but there is little empirical evidence and few preferred choices.

One supervisory agency or more? In terms of the division of responsibility, the Institute of International Bankers reported that of the 70 countries it surveyed in 1998, 44 used discrete agencies for banking, securities markets, and insurance and 19 combined two of the areas. Although the number of single supervisory agencies is growing, as of June 1999, only 8 of 71 countries - Austria, Denmark, Japan, Malta, Norway, the Republic of Korea, Sweden, and the United Kingdom—relied on this arrangement. These 
agencies typically cover prudential and market integrity functions and can also supervise consumer services and competitiveness oversight functions.

Most of the single supervisory agencies are very recent and often were established in response to financial sector problems. Because of this association, it is difficult to judge the costs and benefits of this type of approach. If one focuses only on prudential oversight, there are good conceptual arguments for a single-agency model (Briault 1999; Taylor 1995; Taylor and Fleming 1999). These include increasingly blurred boundaries in financial services, given the links among capital markets, credit markets, insurance instruments, and other financial institutions, as well as the associated emergence of financial conglomerates. These trends make consolidated and integrated approaches to regulation and supervision necessary. A single supervisory agency can also offer economies of scale and scope in regulation and supervision and can avoid the problems of sharing information and coordinating with other agencies. One agency may also result in reduced costs of regulation and the creation of an institution that is more independent, professional, and politically insulated compared with the existing supervisory structure.

At the same time, a single regulatory arm might create the impression that a large range of financial institutions is covered by the public safety net. Such an agency may be too difficult to manage and politically too powerful to maintain its independence. In other contexts, specialization and competition between regulators have been advocated as ways to avoid regulatory capture. Finally, in many countries financial institutions are specialized by function - insurance companies, for example-and need not be supervised by an all-embracing agency.

Institutional or product supervision? Countries with a financial system in which commercial and investment banking activities are separated tend to have an institutional approach to regulation, that is, banks are regulated and supervised by a banking regulator, securities by a separate agency, and so on. In countries in which financial institutions engage in a wide variety of financial activities, this policy offers few advantages because the breakdown of products and services and the distinctions between various providers can result in a serious jurisdictional overlap, making this institutional approach quickly obsolete (Wallman 1999).

In a functional approach, regulation is organized by type of financial product. ${ }^{6}$ For example, a securities exchange commission might regulate the sale of securities whether the seller is a bank, an insurer, or a securities firm. The functional approach can be more efficient and reduce jurisdictional overlap, but it has proven difficult to implement in most countries because of the extensive need for coordination among supervisory agencies. To ensure such coordination, many countries have resorted to the use of a lead coordinator among the various regulators for each finance institution. As product definitions continue to evolve and often defy cat- 
egories, issues of coordination and overlap have increased, with associated risks of incomplete regulatory and supervisory coverage (Scott 1994, 1995).

Regulation and supervision by objectives. Under this approach, supervisory agencies correspond to regulatory objectives (Wallman 1999), with separate regulators for consumer protection, market integrity, systemic risk, and possibly competitiveness issues. Each of these regulators covers all financial institutions and all forms of financial intermediation. For example, to the extent that any financial product is sold to consumers, the consumer watchdog would have jurisdiction. To the extent that any financial institution is very large or is engaged in activities that could pose a risk to the system as a whole, the systemic watchdog has jurisdiction. Institutionally, these regulators could be separate agencies or could be combined in several ways. For example, the systemic regulator could be combined with the market integrity regulator, but not with the consumer protection or competitiveness regulator. Because the nature and methods of regulation and supervision are likely to differ, combining these functions in one institution is not necessarily desirable, at least on the grounds of economies of scale and scope. At the same time, when these functions are not combined in one institution, financial institutions would have to deal with multiple agencies, thereby increasing regulatory costs and possibly offsetting the benefits of regulation by objective.

So far, few countries have adopted this approach. Although differentiating between various objectives may be possible conceptually, in practice such fine discrimination may prove difficult. Concerns about systemic risk and safety nets, for example, may require the regulation and supervision of most of a financial institution's activities, not just its deposits. Systemic risk could, for example, emanate from a universal bank's investment banking activities if losses in investment banking threaten the overall solvency of the institution and the institution is large enough for its failure to have systemic repercussions.

\section{Conclusions}

Competition in the financial sector cannot be analyzed in isolation. The optimal degree of competition requires balancing various concerns, including franchise value, static and dynamic efficiency, the ability to supervise financial institutions, and the scope and institutional context for rent seeking. Country experience-and theory more generally-suggests that competitiveness does not necessarily require many financial institutions because a concentrated system can be competitive if it is contestable. The degree of contestable entry in the financial sector, together with competition from other forms of financial intermediation, is the most important determinant of the performance and efficiency of financial sectors. Openness to foreign banks 
is an important element, and evidence suggests that foreign entry provides important benefits to a country.

The integrated banking model can offer important benefits to financial institutions through economies of scale and scope, diversification of revenue generation, and informational advantages, and to consumers through a reduction of search and transaction costs and lower costs of financial services. The potential costs of providing more integrated financial services - in particular extending the safety net to nondeposit financial services activities — can be mitigated through appropriate safeguards and firewalls, which require proper enforcement and monitoring by the supervisory authority. Countries throughout the world are moving toward the provision of more integrated financial services, and most countries now allow banks to engage in securities underwriting, dealing, and brokering. Furthermore, in countries where banks have latitude to choose their own corporate structure (that is, where to locate the securities unit), most banks choose to adopt the integrated bank model (and locate the securities unit in a department of the bank). There is also evidence that a wide scope of financial services provision enhances financial stability and mitigates the risks of a banking crisis. The preferred organizational design of supervisory functions is less clear, especially as the scope of financial services provided is expanding. Countries have adopted different institutional structures with success. Yet certain structures (for example, supervision by institution) are rapidly becoming obsolete.

\section{Notes}

Stijn Claessens is lead economist and Daniela Klingebiel is senior financial economist in the Financial Sector Strategy and Policy Group of the World Bank. The authors would like to thank Gerard Caprio, Michel Cardona, Patrick Honohan, Larry Promisel, Thomas Rose, and the three reviewers for valuable comments. Additional information can be found in Claessens and Klingebiel (1999).

1. According to Section 20 of the U.S. Bank Holding Company Act, revenues that commercial banks derive from their securities subsidiary (underwriting and dealing activities) cannot make up more than 25 percent of their overall profits. Moreover, commercial banks are not allowed to hold an equity stake in nonfinancial firms (except for trading purposes). Recently adopted proposals in the U.S. Congress will eliminate these restrictions.

2. The question of scope of financial services is then also related to the costs and benefits of bankbased versus capital market-based systems, which in turn may have implications for firms' access to and cost of capital and for economic growth. For an overview of this literature, see Stulz 1999.

3. A billion is one thousand million.

4. An integrated banking system may also lead to greater market concentration and thus has the potential to reduce competition. Another concern has been the concentration of economic power that may come along with commercial banks having a wider scope of activities, including owning nonfinancial institutions. This has been a highly charged issue of political economy, and some countries care more than others about "excessive" concentration. This issue probably relates more to the concentration of economic power in general, including that of nonfinancial institutions, and the degree of competition, rather than to the particular banking model adopted. 
5. For example, when commercial banks undertake investment banking activities, conflicts of interest can arise because of the commercial bank's advisory role to potential investors (for example, the bank may promote the securities of firms it is lending to even when better investments are available in the market) and because of its role as a trust fund manager (the bank may "dump" into the trust accounts it manages the unsold part of the securities it underwrites).

6. For example, bank-type aspects of a product would be regulated by a bank regulator, insurancetype aspects of the product would be regulated by an insurance regulator, the whole product would be regulated by both, or the regulators would have to defer to each other so that one regulator has "primary jurisdiction" and the other has secondary jurisdiction, and so forth. See further Wallman 1999.

\section{References}

The word "processed" describes informally reproduced works that may not be commonly available through library systems.

Ang, James S., and Terry Richardson. 1994. "The Underpricing Experience of Commercial Bank Affiliates prior to the Glass-Steagall Act: A Re-Examination of Evidence for Passage of the Act." Journal of Banking and Finance 18:351-95.

Barajas, Adolfo, Roberto Steiner, and Natalia Salazar. 1999. "Interest Spreads in Banking in Colombia, 1974-96.” International Monetary Fund Staff Papers 46(2):196-224.

_. 2000. "Foreign Investment in Columbia’s Financial Sector." In Claessens and Jansen, eds. The Internalization of Financial Services. The Hague: Kluwer Law International.

Barth, James R., Gerard Caprio Jr., and Ross Levine. 1999. "Banking Systems around the Globe: Do Regulation and Ownership Affect Performance and Stability?” Policy Research Working Paper 2325. World Bank, Development Research Group, Washington, D.C. Processed.

Benston, G. J. 1990. The Separation of Commercial and Investing Banking: The Glass-Steagall Act Revisited and Reconsidered. New York: Oxford University Press.

Berger, Allen N., and G. F. Udell. 1996. "Universal Banking and the Future of Small Business Lending.” In Ingo Walter and Anthony Saunders, eds., Universal Banking: Financial System Design Reconsidered. Chicago: Irwin.

Berger, Allen N., Rebecca S. Demsetz, and Philip E. Strahan. 1999. "The Consolidation of the Financial Services Industry: Causes, Consequences, and Implications for the Future.” Journal of Banking and Finance 23:135-94.

Berger, Allen N., G. A. Hanweck, and D. B. Humphrey. 1987. "Competitive Viability in Banking: Scale, Scope, and Product Mix Economies.” Journal of Monetary Economics 20(December):501-20.

Berger, Allen N., William C. Hunter, and Stephen G. Timme. 1993. "The Efficiency of Financial Institutions: A Review of Research Past, Present, and Future.” Journal of Banking and Finance 17:221-49.

Bhattacharya, Amar, C. A. K. Lovell, and P. Sahay. 1997. "The Impact of Liberalization on the Productive Efficiency of Indian Commercial Banks.” European Journal of Operational Research 98:332-45.

Boyd, John H., Chun Chang, and Bruce D. Smith. 1998. "Moral Hazard under Commercial and Universal Banking." Journal of Money, Credit, and Banking 30(2):426-71.

Brewer, E. III, D. Fortier, and C. Pavel. 1989. "Bank Risk from Nonbank Activities.” Journal of International Securities Markets 3:199-210.

Briault, Clive. 1999. “The Rationale for a Single National Financial Services Regulator.” Occasional Paper Series 2. United Kingdom, Financial Services Authority, London. http://www.fsa.gov.uk/pdf/ policy/fsa_op02.pdf. 
Claessens, Stijn, and Tom Glaessner. 1999. "The Internationalization of Financial Services in Asia.” In James Hanson and Sanjay Kathuria, eds., India: A Financial Sector for the Twenty-First Century. New York: Oxford University Press.

Claessens, Stijn, and Marion Jansen, eds. 2000. The Internationalization of Financial Services. The Hague: Kluwer Law International.

Claessens, Stijn, and Daniela Klingebiel. 1999. “Alternative Frameworks for Providing Financial Services.” Policy Research Working Paper 2189. World Bank, Financial Sector Strategy and Policy Group, Washington, D.C. Processed.

Claessens, Stijn, Asli Demirgüç-Kunt, and Harry Huizinga. 2001. "How Does Foreign Entry Affect the Domestic Banking Market?" Journal of Banking and Finance, 25(5).

Clark, Jeffrey A. 1988. "Economies of Scale and Scope at Depository Financial Institutions: Review of the Literature.” Federal Reserve Bank of Kansas City Economic Review (September/October):16-33.

Clarke, George, Robert Cull, Laura D’Amato, and Andrea Molinari. 2000. "On the Kindness of Strangers? The Impact of Foreign Entry on Domestic Banks in Argentina.” In Claessens and Jansen, eds. The Internalization of Financial Services. The Hague: Kluwer Law International.

Demirgüç-Kunt, Asli, and Harry Huizinga. 1999. "Determinants of Commercial Bank Interest Margins and Profitability: Some International Evidence.” World Bank Economic Review 13(2):379408 .

Demirgüç-Kunt, Asli, Ross Levine, and H. Min. 1998. "Opening to Foreign Banks: Issues of Stability, Efficiency, and Growth." In Proceedings of the Bank of Korea Conference on The Implications of Globalization of World Financial Markets. Seoul: Bank of Korea.

Denizer, Cevdet. 1997. "The Effects of Financial Liberalization and New Bank Entry on Market Structure and Competition in Turkey.” Policy Research Working Paper 1839. World Bank, Development Research Group, Washington, D.C. Processed.

—. 2000. "Foreign Entry in Turkey’s Banking Sector, 1980-1997.” In Claessens and Jansen, eds. The Internalization of Financial Services. The Hague: Kluwer Law International.

Eisenbeis, Robert, and Larry D. Wall. 1984. "Risk Considerations in Deregulating Bank Activities." Economic Review Federal Reserve Bank of Atlanta 69(May special issue):6-19.

Gardener, Edward P. M., Philip Molyneux, B. Moore, and L. A. Winters. 2000. "The Impact of the Single Market Programme on EU Banking: Select Policy Experiences for Developing Countries." In Claessens and Jansen, eds. The Internalization of Financial Services. The Hague: Kluwer Law International.

Gruben, William C., and Robert P. McComb. 1999. "Privatization, Competition, and Supercompetition in the Mexican Commercial Banking System.” Research Department Working Paper (U.S.) 99-04. Federal Reserve Bank of Dallas. Processed.

Hao, Jonathan, William C. Hunter, and Won Keun Yang. 1999. "Deregulation and Efficiency: The Case of Private Korean Banks.” In William C. Hunter, George G. Kaufman, and Thomas H. Krueger, eds., The Asian Financial Crisis: Origins, Implications, and Solutions. Boston: Kluwer Academic Press for the Federal Reserve Bank of Chicago and the International Monetary Fund.

Honohan, Patrick. 2000. "Consequences for Greece and Portugal of the Opening Up of the European Banking Market.” In Claessens and Jansen, eds.

Honohan, Patrick, and Joseph E. Stiglitz. 1999. "Robust Financial Constraint." Paper presented at the workshop on "Financial Liberalization: How Far? How Fast," sponsored by World Bank, Development Research Group, Washington, D.C. (March). Processed.

Hunter, William C., Stephen G. Timme, and Won Keun Yang. 1990. "Examination of Cost Subadditivity and Multiproduct Production in Large U.S. Banks." Journal of Money, Credit, and Banking 22(November):504-25. 
John, Kose, Teresa A. John, and Anthony Saunders. 1994. "Universal Banking and Firm Risk Taking." Journal of Banking and Finance 18(December):307-23.

Kane, Edward. J. 1996. "The Increasing Futility of Restricting Bank Participation in Insurance Activities." In Ingo Walter and Anthony Saunders, eds., Universal Banking: Financial System Design Reconsidered. Chicago: Irwin.

Kelly, E. J. 1985. “Conflicts of Interest: A Legal View.” In Ingo Walter, ed., Deregulating Wall Street: Commercial Bank Penetration of the Corporate Securities Market. New York: John Wiley \& Sons.

Kiraly, Julia, with B. Majer, L. Matyas, B. Ocsi, A. Sugar, and E. Varhegyi. 2000. "Experience with Internationalization of Financial Services Provision Case-Study: Hungary.” In Claessens and Jansen, eds. The Internalization of Financial Services. The Hague: Kluwer Law International.

Klein, Peter, and Marc R. Saidenberg. 1998. "Diversification, Organization, and Efficiency: Evidence from Bank Holding Companies.” University of Georgia and Federal Reserve Bank of New York. Processed.

Kroszner, Randall S., and Raghuram Rajan G. 1994. "Is the Glass-Steagall Act Justified? A Study of the U.S. Experience with Universal Banking before 1933.” American Economic Review 84:810-32.

Kwan, Simon H. 1997. "Securities Activities by Commercial Banking Firms' Section 20 Subsidiaries: Risk, Return, and Diversification Benefits.” Federal Reserve Bank of San Francisco. October.

Laeven, Luc. 1999. "Risk and Efficiency in East Asian Banks." Policy Research Paper 2255. World Bank, Washington, D.C. Processed.

Lang, G., and P. Welzel. 1995. "Technology and Cost Efficiency in Banking: A Thick Frontier Analysis of the German Banking Industry.” Discussion Paper 130. University of Augsburg, Augsburg, Germany. Processed.

Levine, Ross. 1996. "Foreign Banks, Financial Development and Economic Growth.” In Claude E. Barfield, ed., International Financial Markets. Washington, D.C.: American Enterprise Institute.

Noulas Athanosios G., Subhash C. Ray, and Stephan M. Miller. 1990. "Returns to Scale and Input Substitution for Large U.S. Banks.” Journal of Money, Credit, and Banking 22(February):94-108.

Pastor, Jose M., Francisco Perez, and Javier Quesada. 2000. “The Opening of the Spanish System: 198598.” In Claessens and Jansen, eds. The Internalization of Financial Services. The Hague: Kluwer Law International.

Petersen, Mitchell, and Raghuram Rajan.1994. "Benefits of Lending Relationships: Evidence from Small Business Data." Journal of Finance 49(March):3-37.

Puri, Manju. 1994. "The Long-Term Debt Default Performance of Bank Underwritten Security Issues.” Journal of Banking and Finance 18:397-418.

1996. "Commercial Banks in Investment Banking: Conflict of Interest or Certification Role?" Journal of Financial Economics 40:373-401.

Ramirez, Carlos D. 1995. "Did J. P. Morgan Men Add Liquidity: Corporate Investment, Cash-Flow, and Financial Structure at the Turn of the Century." Journal of Finance 50:661-78.

Santos, João A. C. 1997a. "Bank Capital and Equity Investment Regulations.” Federal Reserve Bank of Cleveland. February.

1997b. "Securities Activities in Banking Conglomerates: Should Their Location Be Regulated?" Federal Reserve Bank of Cleveland. April.

1998. "Commercial Banks in the Securities Business: A Review.” BIs working paper 56:1-29. Bank for International Settlements, Monetary and Economic Department, Basle (June). Processed.

Saunders, Anthony. 1985. “Conflicts of Interest: An Economic View.” In Ingo Walter, ed., Deregulating Wall Street: Commercial Bank Penetration of the Corporate Securities Market. New York: John Wiley \& Sons. 
1994. "Banking and Commerce: An Overview of the Public Policy Issues.” Journal of Banking and Finance 18:231-54.

Saunders, Anthony, and Ingo Walter. 1994. Universal Banking in the United States. Oxford: Oxford University Press.

Scott, David H. 1994. “The Regulation and Supervision of Domestic Financial Conglomerates.” Policy Research Paper 1329. World Bank, Financial Sector Development Department, Washington, D.C. Processed.

—. 1995. "Regulation and Supervision of Financial Conglomerates: The New Groupwide Approach and What It Means for World Bank Operations." Financial Sector Development Department Note 36. World Bank, Washington, D.C. Processed.

Schwartz, Amy J. 1992. "Misuse of the Fed's Discount Window.” Review Federal Reserve Bank of St. Louis 74(September/October):58-69.

Shaffer, Sherrill. 1993. "Test of Competition in Canadian Banking." Journal of Money, Credit, and Banking 25:49-61.

Stiglitz, Joseph E. 2001. "Principles of Financial Regulation: A Dynamic Portfolio Approach." World Bank Research Observer 16:1-18.

Stulz, Rene M. 1999. "Financial Structure, Corporate Finance, and Economic Growth." Ohio State University (April). Processed.

Taylor, Michael. 1995. "Bank Supervision: Model Solutions.” Central Banking (U.K.) 6:74-79.

Taylor, Michael, and Alex Fleming. 1999. "Integrated Financial Supervision: Lessons from Northern European Experience." Policy Research Working Paper 2223. World Bank, Development Research Group, Washington, D.C. Processed.

Vander Vennet, Rudi. 1994. "Economies of Scale and Scope in Ec Credit Institutions." Cahiers Economiques de Bruxelles 144:507-48.

— 1999. "Cost and Profit Dynamics in Financial Conglomerates and Universal Banks in Europe." University of Gent, Gent, Belgium (May). Processed.

Vives, Xavier. 2000. "Lessons from European Banking Liberalization and Integration” In Claessens and Jansen, eds. The Internalization of Financial Services. The Hague: Kluwer Law International.

Wallman, Steven M. H. 1999. "The Information Technology Revolution and its Impact on Regulation and Regulatory Structure.” In Robert E. Litan and Anthony M. Santomero, eds., Papers on Financial Services. Washington, D.C.: Brookings Institution Press.

White, Eugene. 1986. "Before the Glass-Steagall Act: An Analysis of the Investment Banking Activities of National Banks." Explorations in Economic History 23:33-55. 